|||||||||||||||||||||||||||||||||

研究論文

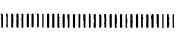

\title{
球状アルミナ粒子で強化した6061アルミニウム合金 複合材料の機械的性質と組織
}

\author{
王経濤*·古川 稔**. 堀田 善治*** \\ 根本 實*** $\cdot$ Y. MA M $^{* * *} \cdot$ T. G. LANGDON****
}

Mechanical properties and microstructure of 6061 aluminum alloy

matrix composite reinforced with alumina microspheres

Jingtao WANG*, Minoru FURUKAWA**, Zenji HORITA***

Minoru NEMOTO***, Yan MA*** and Terence G. LANGDON****

\begin{abstract}
Experiments were conducted on a composite material (Comral-85) fabricated by ingot metallurgy. The composite consisted of a 6061 aluminum alloy matrix and a reinforcement of $20 \mathrm{vol} \% \mathrm{Al}_{2} \mathrm{O}_{3}$-based microspheres having an average diameter of $20 \mu \mathrm{m}$. The age hardening behavior, temperature dependence of the yield stress and the creep behavior of the composite after extrusion were investigated and compared with those of 6061 aluminum alloy. In the as-quenched state, the yield stress of the composite is $40 \sim 85 \mathrm{MPa}$ higher than that of the 6061 alloy. This difference is attributed to the high density of dislocations within the matrix which are introduced by the difference in thermal expansion coefficients between the matrix and the reinforcement. The difference in yield stress between the composite and the 6061 alloy decreases with aging time and the age hardening curves for both materials have a similar trend. At room temperature, the strain hardening rate of the composite is higher than that of the 6061 alloy, probably because the distribution of reinforcement enhances the dislocation density during deformation. Both the yield stress and the strain hardening rate of the T6-treated composite decrease as the testing temperature increases, and the rate of decrease is faster in the composite than in the 6061 alloy. Under creep conditions, the stress exponents of the T6-treated composite vary from 8.3 at $473 \mathrm{~K}$ to 4.8 at $623 \mathrm{~K}$. These exponents are larger than those of the 6061 matrix alloy.
\end{abstract}

Keywords: microsphere reinforced composite, yield stress, temperature dependence, strain hardening rate, creep behavior

(Received September 8, 1993)

\section{1. 緒言}

金属基複合材料は, 連続緎維強化型に限らず不連続緎 維強化型においても高い強度特性を示すことが1960年代 に明らかにされて以来, 自動車, 宇宙·航空材料として の本格的な実用化をめざして数多くの研究がなされてき た1)。なかでも，アルミニウム基の複合材料は比強度, 比剛性などが重要視される用途に対して有望な材料とし て注目されている21,3)。これらに用いられる強化材とし ては, 炭素, $\mathrm{SiC}, \mathrm{Al}_{2} \mathrm{O}_{3}$, 泀う素などの長繊維，あるい は $\mathrm{SiC}, \mathrm{Si}_{3} \mathrm{~N}_{4}$ などのウィスカ,さらに各種のセラミッ
クスの微粉末などが考えられている4)。そのなかで，粒 子を分散させたアルミニウム合金は, 耐摩耗性や吸振性 等に関してウィスカ添加合金に近い効果が得られてい る, 性能が等方的である, 複雑形状のものが従来の鋳造 法と加工法により作れるため安価であるなどの利点があ

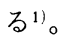

これらの作製には，主に粉末治金法と鋳造法が用いら れるが，製造コスト的には鋳造法が有利である。また， 高強度を得るために，マトリックス合金としては時効硬 化性をもつ2000，6000，7000番台の合金が用いられる。

最近，鋳造法によりアルミナを主成分とした平均直径

* 九州大学工学部 [現在 : 西安治金建筑学院 (西安市, 中国)]。Faculty of Engineering, Kyushu University [Present: Department of Metallurgy, Xian Institute of Metallurgy and Construction Engineering (Xian, China)].

** 福岡教育大学 (宗像市)。Department of Technology, Fukuoka University of Education (Munakata-shi, Fukuoka)

*** 九州大学工学部 (福岡市)。Faculty of Engineering, Kyushu University (Fukuoka-shi, Fukuoka).

**** Departments of Materials Science and Mechanical Engineering, University of Southern California (Los Angeles, USA). 
Table 1 Chemical composition of specimens (mass\%)

\begin{tabular}{l|ccccccc}
\hline \hline & $\mathrm{Mg}$ & $\mathrm{Si}$ & $\mathrm{Cu}$ & $\mathrm{Fe}$ & $\mathrm{Ti}$ & $\mathrm{Mn}$ & $\mathrm{Cr}$ \\
\hline Composite A & 0.90 & 0.68 & 0.27 & 0.22 & 0.11 & - & - \\
Composite B & 0.66 & 0.60 & 0.12 & 0.23 & 0.088 & 0.09 & 0.05 \\
6061 A alloy & 0.80 & 0.76 & 0.16 & 0.22 & 0.009 & 0.12 & 0.07 \\
6061 B alloy & 0.82 & 0.58 & 0.26 & 0.14 & 0.011 & 0.10 & 0.11 \\
6061 C alloy & 1.00 & 0.71 & 0.30 & 0.32 & 0.03 & 0.11 & 0.14 \\
6061 D alloy & 0.98 & 0.56 & 0.34 & 0.15 & 0.03 & 0.07 & - \\
\hline
\end{tabular}

$20 \mu \mathrm{m}$ の球状粒子を $20 \mathrm{vol} \%$ 含む6061アルミニウム合金 が開発され，低コストでしかも高疲労強度と高弾性率を 示すことから注目を集めている(5),6)。しかし，本複合材 料0)時効硬化性については, マトリックス合金より時効 が促進され，ピーク硬さ值が上昇するといら簡単な硬さ 測定結果 ${ }^{7}$ はあるものの, 塑性変形挙動や組織变化につ いては明らかにされていない。また，高温強度について はクリープ特性の報告が一例あるのみである ${ }^{8)}$ 。

本研究では, この複合材料の時効特性, 室温から高温 （723 K）までの降伏応力の温度依存性およびクリープ 特性をマトリックス合金と比較・検討した。

\section{2. 実験方法}

本実験に用いた複合材料は，オーストラリアの Comalco Research Center で開発・製造された Comral-85で ある。 $35 \mathrm{~kg}$ の溶融6061アルミニウム合金に，コランダ ム $\left(\alpha-\mathrm{Al}_{2} \mathrm{O}_{3}\right)$ を主体としてムライト $\left(3 \mathrm{Al}_{2} \mathrm{O}_{3}-2 \mathrm{SiO}_{2}\right)$ を含む微細粒子（Micral-20）を予熱後添加し，擋拌· 鋳込みにより直径 $127 \mathrm{~mm}$ ，長さ $300 \mathrm{~mm}$ のビレットと した。添加粒子の平均直径は20 $\mu \mathrm{m}$ ，体積率は $20 \%$ であ

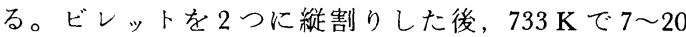
$\mathrm{m} / \mathrm{min}$ の速度で押出加工し直径 $19 \mathrm{~mm}$ のロッド状とし た ${ }^{5)}$ 。本実験では, 比較材としてマトリックス組成に相 当する市販の6061合金を用いた。Table 1 には，本実験 に用いた試料の化学分析值を示す。一つのバッチから入 手できた材料がわずかずつであったので，2 種類の複合 材料と 4 種類の6061合金として区別して示した。用いた 材料中の主要成分であるマグネシウム（Mg）とけい素 ( $\mathrm{Si})$ の組成值は各試料においてかなりのばらつきがあ るが，複合材料 $\mathrm{B}$ の Mg の值を除いて6061合金の基準 組成である $\mathrm{Mg}: 0.8 \sim 1.2 \%, \mathrm{Si}: 0.4 \sim 0.8 \%$ 範囲内に ある。

これらの試料から，圧縮試験片として $3 \mathrm{~mm} \times 3 \mathrm{~mm}$ $\times 5 \mathrm{~mm}$ ，クリープ試験片として直径 $3.2 \mathrm{~mm}$, ゲージ長 $25.4 \mathrm{~mm}$ のダンベル状に切出した後, $803 \mathrm{~K}$ で5.4 ks 溶 体化処理後氷水焼入れし，448 K で時効処理を行った。 これらの熱処理にあたっては，試料をアルゴンガスとと

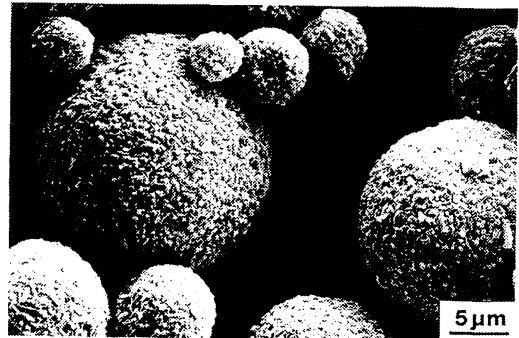

Fig. 1 SEM micrograph showing ceramic microspheres.

もにパイレックスガラス管中に封入して行った。時効 後, 約 $3 \%$ 塑性ひずみまでの圧縮試験によって降伏応力 を測定した。T6処理（448 K において28.8 ks 時効）し た試料について，室温から723 K の温度範囲において降 伏応力の温度依存性を求めた。また, 同じく $\mathrm{T} 6$ 処理し た試料について，473 K から673 K の範囲の各温度でク リープ試験を行った。これらの時効後または変形後の試 料から，精密切断機により約 $0.3 \mathrm{~mm}$ 厚さの薄板を切出 し，20\%過塩素酸-80\%エチルアルコール電解液を用い てッインジェット法により透過電子顕微鏡用薄膜を作製 した。複合材料については電解研磨後, イオンミリング により薄膜とした。

\section{3. 実験結果および考察}

\section{1 押出し後の組織}

Fig. 1 に，溶湯に添加する前の強化粒子の SEM 組織 を示す。粒子はほぼ完全な球状で，表面には多〈の> セットがあり，個々の結晶粒が識別できる。Fig. 2 に は, 押出し後 $\mathrm{T} 6$ 処理を施した複合材料 $\mathrm{A}$ の縦断面の光 学顕微鏡組織を示す。添加粒子は押出材中においてほほ 均一に分布していることがわかる。また，Fig. 3 は押出 し後 $\mathrm{T} 6$ 処理を施した複合材料 $\mathrm{A}$ のマトリックスを電解 研磨により溶解して取出した粒子の SEM 像であるが, 粒子にはFig. 1に見られるようなファセットは認めら れず, 溶融・擋拌中に粒子表面とマトリックスは反応し たものと考兄られる。複合材料中の球状粒子とマトリッ クスの界面にはスピネル構造をもつ $\mathrm{MgAl}_{2} \mathrm{O}_{4}$ と bcc 構 造をもつ $\alpha-\mathrm{AlFeSi}$ が形成され, $\mathrm{MgAl}_{2} \mathrm{O}_{4}$ の形成はマト リックスの $\mathrm{Mg}$ を消費し，一方 $\alpha-\mathrm{AlFeSi}$ の形成は添加 粒子とマトリックスから Si を消費することがすでに報 告されている77,9)ため，マトリックスの組成は変化して いる可能性がある。

\section{2 時効硬化曲線と析出組織}

Fig. 4 に, $803 \mathrm{~K}$ で $5.4 \mathrm{ks}$ 溶体化処理後水水焼入れし $448 \mathrm{~K}$ で時効した試料を圧縮試験したときの降伏応力 $(0.2 \%$ 耐力 $)$ の時効時間による变化を示す。溶体化処理 


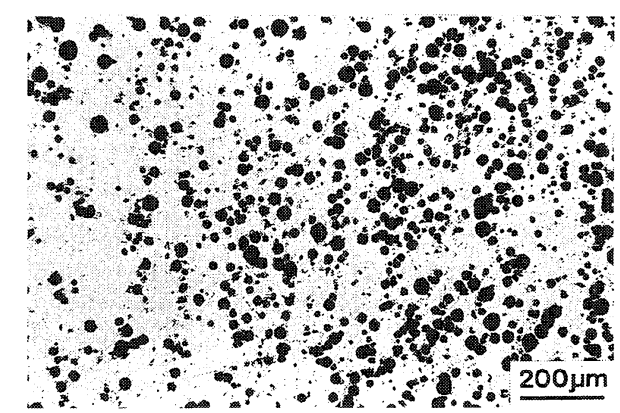

Fig. 2 Optical micrograph of composite A aged at $448 \mathrm{~K}$ for $28.8 \mathrm{ks}$ after solution heating at $803 \mathrm{~K}$ for $5.4 \mathrm{ks}$ and cold water quenching.

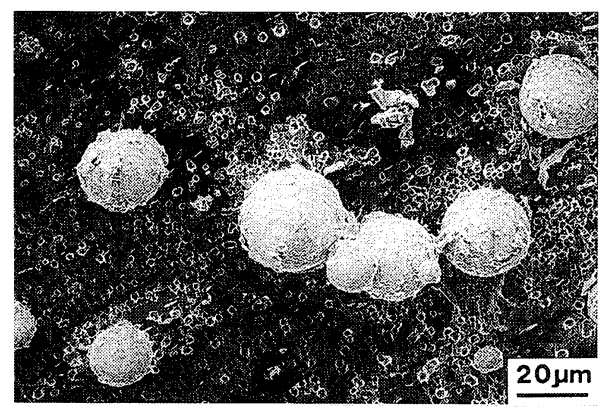

Fig. 3 SEM micrograph of composite A.

後水水焼入れした状態では，複合材料の方が6061合金に 比べて40〜85 MPa 高い強度を示している。分散粒子の 間隔は約 $30 \mu \mathrm{m}$ であり，これから予測される Orowan 応 力は約 $3 \mathrm{MPa}$ しかなく, 単純な分散強化では説明でき ない。

Fig. 5 には，その状態での転位組織を示す。同図 (a) に見られる複合材料 B 中の高密度の転位は，Dutta らの 報告 ${ }^{10)}$ にあるように，焼入れ過程において添加粒子 とマトリックスの熱膨張係数の差 (Al : $23 \times 10^{-6} / \mathrm{K}$, $\left.\mathrm{Al}_{2} \mathrm{O}_{3}: 8 \times 10^{-6} / \mathrm{K}\right)$ により生じたものと考えられる。 複合材料 B では, 転位は Fig. 5(a) に示すように, 左上 部に見られる添加粒子近傍にのみ特に多いといらことで はなく、マトリックス全体にほぼ均一に分布している。 一方6061B 合金では, Fig. 5(b)に示すよ5に局所的にラ ンダムな転位配列や小角粒界が見られるが，他の部分の 転位密度は低かった。平均の転位密度は複合材料 B で は約 $1.5 \times 10^{13} \mathrm{~m}^{-2}, 6061 \mathrm{~B}$ 合金では約 $2.4 \times 10^{11} \mathrm{~m}^{-2}$ であ った。Dutta らは, $\mathrm{Al}_{2} \mathrm{O}_{3}$ 強化材を $15 \mathrm{vol} \%$ 含む6061合金 複合材料について, 溶体化処理後水水焼入れ状態で, $7.8 \times 10^{12} \mathrm{~m}^{-2}$ の転位密度を報告している10)。添加粒子 の体積率の違いを考慮すると, 本実験の結果と Dutta ら の結果はほぼ一致していると考えられる。

本実験での両材料の転位密度の差から， $\tau_{\mathrm{disl}}=\alpha \mu b \rho^{1 / 2}$

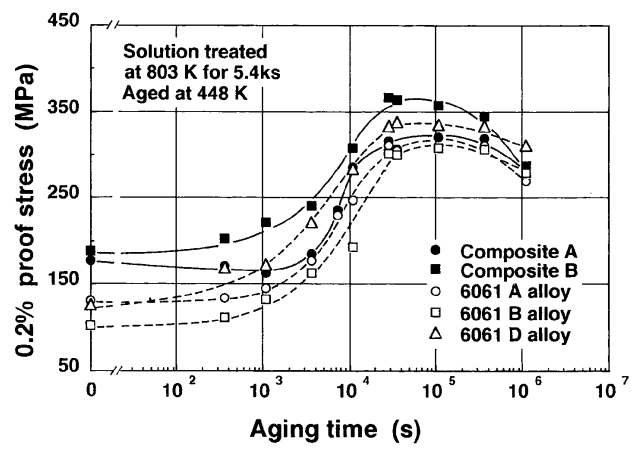

Fig. 4 Variation of $0.2 \%$ proof stress with aging time. Specimens were solution-treated at $803 \mathrm{~K}$ for $5.4 \mathrm{ks}$, quenched into iced water and aged at $448 \mathrm{~K}$.
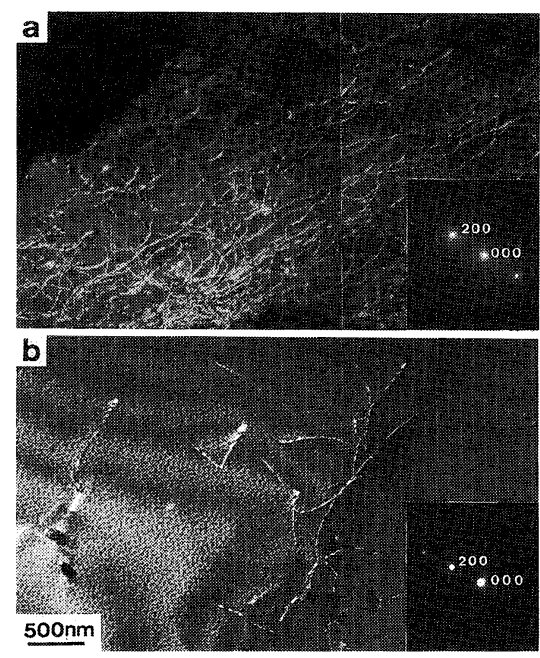

Fig. 5 (200) dark field images of composite B (a) and $6061 \mathrm{~B}$ alloy (b) after quenching.

の式より求めた転位による強化量は約 $29 \mathrm{MPa}$ となる。 ここで定数 $\alpha=0.4$, 剛性率 $\mu=26 \mathrm{GPa}$ ，バーガース. ベクトル $b=0.286 \mathrm{~nm}$, Taylor 因子 2.5 を用いた。この值 より, 溶体化処理後水水焼入れ状態での両者の強度差 $85 \mathrm{MPa}$ の35\%程度が，焼入れ中に導入された転位によ るものと考えられる。

Fig. 4 より, 複合材料抢よび 6061 合金はともに448 K での時効により降伏応力は高をることがわかる。試料間 にかなりのばらつきはあるものの, 約 $3 \mathrm{ks}$ 時効後には 両者の降伏応力の差は縮まる傾向にある。

最大強度を示す時点での析出組織を Fig. 6 に示す。 6061 合金中の析出過程は, 球状 GP ゾーン $\rightarrow$ 針状 GP ゾ 一ン $\rightarrow$ 整合な針状 $\beta^{\prime \prime}$ 相 $\rightarrow$ 半整合の棒状 $\beta^{\prime}$ 相 $\rightarrow$ 板状の平 衡 $\beta$ 相（ $\mathrm{Mg}_{2} \mathrm{Si} ）$ であることが報告されている(1)。Fig. 6 においても，〈100〉方向に平行に微細な $\beta$ ”相が針状に 析出している。この $\beta^{\prime \prime}$ 析出物のサイズと分布には, 複 合材料 B と6061B 合金の間に大きな差は認められない。 

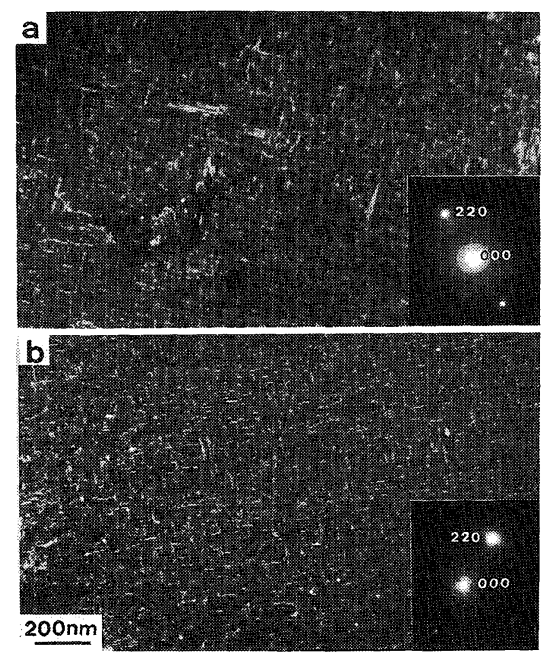

Fig. 6 (220) dark field images of composite B (a) and $6061 \mathrm{~B}$ alloy (b) aged at $448 \mathrm{~K}$ for $28.8 \mathrm{ks}$.

複合材料 B 中には，溶体化処理後氷水焼入れ過程で導 入された転位上に核発生したと考兄られる，ラス状の析 出物が観察される。これらのラス状析出物の強度への寄 与は, 両者の材料の強度の差から見て小さいものと考光 られる。

過時効段階での析出組織を Fig. 7 亿示す。Fig. 6 亿 比べていずれの材料においても析出物は棒状に成長して おり， $\beta^{\prime}$ 相であると考えられる。この時効段階でも， 複合材料 B には転位上の粗大なラス状析出物が見られ る。

Dutta らは, 6061合金に粒状の $\mathrm{Al}_{2} \mathrm{O}_{3}$ 粒子を添加し， 鋳造法により作製した複合材料の場合，析出硬化の速度 はマトリックス合金より速く，しかもその最高硬さは高 くなることを報告している10)。その理由は，複合材料中 の高密度の転位上に $\beta^{\prime \prime}$ 相の析出がおこり,さらに転位 の存在が $\beta^{\prime \prime}$ 相の成長に重要な $\mathrm{Mg}$ の拡散を増大させる ためであるとしている。本実験と同じ Comral-85複合材 料を用いた実験に抋いても，硬さ測定により，複合材料 では時効が促進されると報告している7)。この理由は， 複合材料のマトリックス中の過㮃 $\mathrm{Si}$ の存在と, 焼入れ 速度が小さいことによる焼入れ中の析出の進行によると 説明されている7)。しかし本実験においては，異なるバ ッチから得た複数の試料を用いたため試料間に降伏応力 のばらつきがあるものの, 時効硬化曲線の最高強度やそ の時効時間において，複合材料とマトリックス合金との 間で大きな差は認められない。また，時効析出の主要成 分である $\mathrm{Mg}$ と $\mathrm{Si}$ の量打よびその比率と時効強化量や 最高強度に達する時間との間に, 系統性も認められな い。
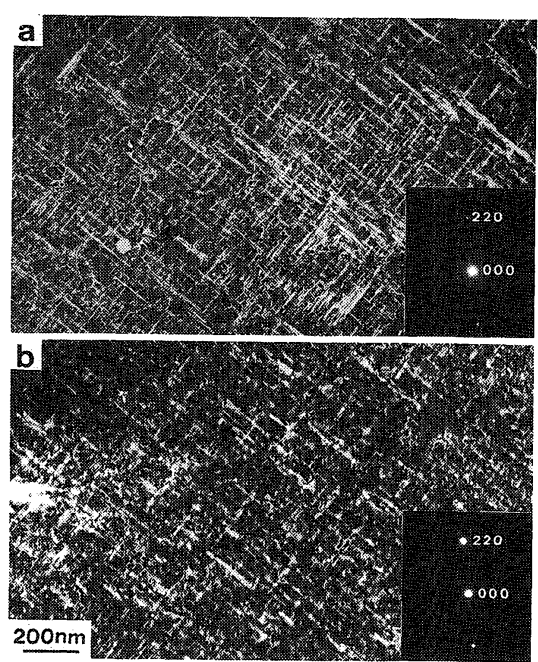

Fig. 7 (220) dark field images of composite B (a) and $6061 \mathrm{~B}$ alloy (b) aged at $448 \mathrm{~K}$ for $108 \mathrm{ks}$ (overaged).

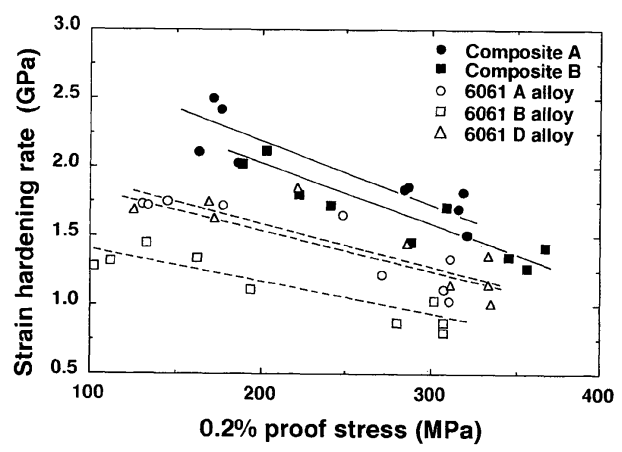

Fig. 8 Variation of strain hardening rate with $0.2 \%$ proof stress.

Fig. 4 において焼入れ後の時効による硬化量は，6061 合金では平均 $205 \mathrm{MPa}$ 程度である。一方, 複合材料で の硬化量は約 $155 \mathrm{MPa}$ であり, 6061合金の硬化量の76 \%と少ない。これは, 複合材料は添加粒子を $20 \%$ 含んで いるため，時効中の強度上昇には残り $80 \%$ のマトッック スのみの時効硬化が寄与するため，および界面反応によ り $\mathrm{Mg}$ と Siが消費されるためであると考兄られる。

\section{3 塑性変形挙動}

各時効段階の複合材料と6061合金を，室温において䄪 $3 \%$ 塑性ひずみまで圧縮試験した際の応力ーひずみ曲線 から, 降伏後 $1 \%$ 塑性変形点の加工硬化率を読及取り, 降伏応力に対してプロットしたものが Fig. 8 である。 加工硬化率は両方の材料ともに降伏応力の上昇に伴い: 汪直線的に低下する傾向を示すが，同一降伏応力で比較 すると，加工硬化率は複合材料の方が6061合金よりも高 い。このことは, 複合材料の室温に掂汀る塑性変形には 


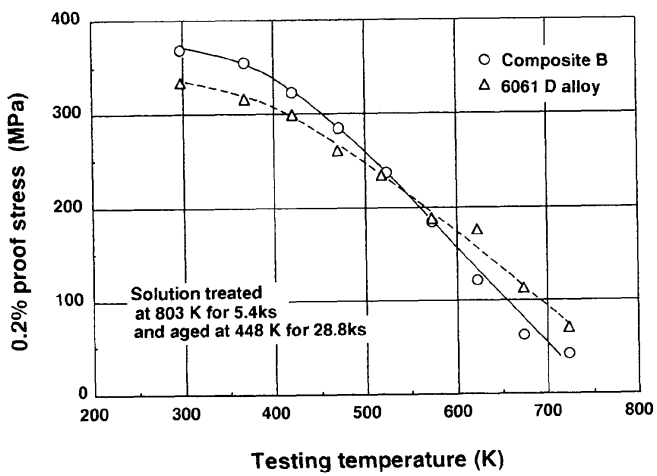

Fig. 9 Temperature dependence of $0.2 \%$ proof stress.

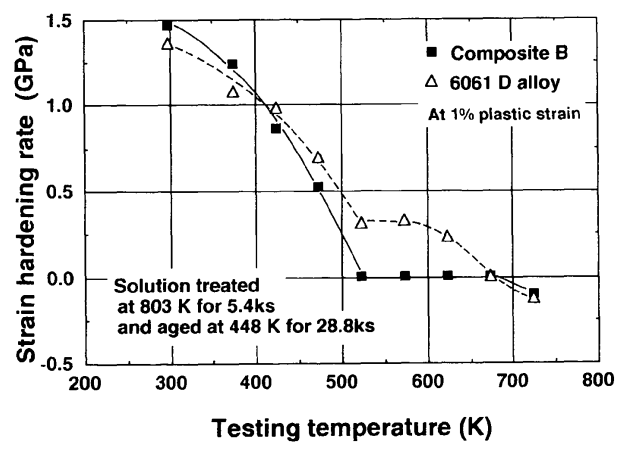

Fig. 10 Temperature dependence of strain hardening rate.

分散粒子が明らかに影響を及ほし，変形により導入され る転位密度は複合材料の方が高いことを示している。

\section{4 強度の温度依存性}

Fig. 9 に, T6 処理後の複合材料 B と6061D 合金の降 伏応力の温度依存性を示す。降伏応力は両者ともに試験 温度の上昇に伴い単調に減少するが，その傾向は前者の 方が著しい。室温では, 複合材料 B の降伏応力は6061D 合金上り約 $40 \mathrm{MPa}$ 程度高い值を示しているが， $550 \mathrm{~K}$

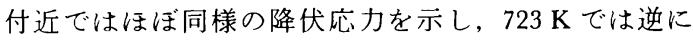
$6061 \mathrm{D}$ 合金の方が20 MPa 程度高い值を示している。

Fig. 10は，T6 処理を施した試料を高温圧縮試験した 際の応力ーひずみ曲線から, 降伏後 $1 \%$ 塑性変形後の加 工硬化率を求め, 試験温度に対してプロットしたもので ある。室温では複合材料 $\mathrm{B}$ の方が6061D 合金より大き な加工硬化率を示すが, $400 \mathrm{~K}$ 以上の試験温度では逆に 6061合金の方が大きくなる。650 K 以上では両者ともに 同様の值を示している。

\section{5 クリープ特性}

Fig. 11 に，複合材料 A と6061C 合金を473 K から $673 \mathrm{~K}$ の範用の各温度において, クリープ試験したとき の応力と最小ひずみ速度との関係を示す。図中には,

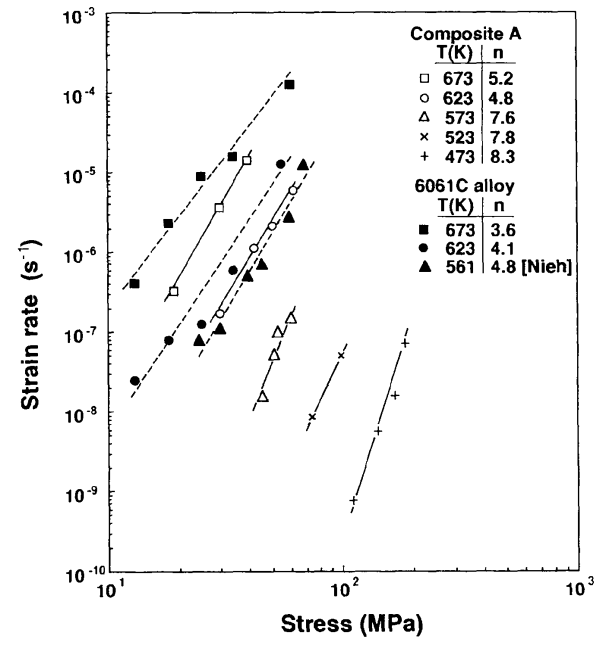

Fig. 11 Variation of minimum strain rate with stress. Specimens were aged at $448 \mathrm{~K}$ for $28.8 \mathrm{ks}$.

Niehによる6061合金についての結果 ${ }^{12)}$ 合わせて示し てある。両材料ともに，これらの試験温度においては, 応力と最小ひずみ速度の対数との間に直線関係があるこ とがわかる。また本実験で調べた応力の範囲では，複合 材料 $\mathrm{A}$ のクリープ強度の方が6061C 合金より高いこと がわかる。 $\partial \ln \dot{\varepsilon} / \partial \ln \sigma て ゙$ 定義される応力指数（ $n$ 值） は, 複合材料 $\mathrm{A}$ では試験温度の上昇とともに $473 \mathrm{~K} て ゙$ の 8.3 から $623 \mathrm{~K} て ゙ の 4.8$ まで減少する傾向にある。この ことは, 添加粒子とマトリックスの熱的なミスマッチが 高温になるほど解消されることで説明される8)。同一試 験温度で比較すると，たとえば $673 \mathrm{~K} て ゙ は ， ~ n$ 值は複合 材料 A では5.2, 6061C 合金では3.6を示し, 複合材料 A の方が高い值を示している。一般に純金属や固溶体合金 に分散粒子が含まれる場合, $n$ 値は増加することが報告 されている(13)。本実験では分散粒子の大きさが $20 \mu \mathrm{m}$ と 大きいにもかかわらず, 粒子添加によるn值の増加が認 められる。

変形のひずみ速度がより速い圧縮試験（ひずみ速度： $\left.3.3 \times 10^{-4} \mathrm{~s}^{-1}\right)$ では, 試験温度上昇による強度低下傾向 は複合材料の方が6061合金より著しい。加工硬化率は Fig. 10 より $400 \mathrm{~K}$ 以上で, 強度はFig. 9 より $550 \mathrm{~K}$ 以上 で複合材料の方が低い。Fig. 11 の $673 \mathrm{~K}$ でのクリープ試 験による複合材料 A と6061C 合金についての応力と最 小ひずみ速度との間の直線関係は, より高ひずみ速度ま で延長すると，ほぼ $2 \times 10^{-4} \mathrm{~s}^{-1}$ で交わる。つまり，よ り大きなひずみ速度では, 複合材料 $\mathrm{A}$ の方が低い応力 で変形することになり, Fig. 9 の圧縮試験の結果とよく 一致する。ひずみ速度の違いにより複合材料と6061合金 の高温強度が逆転する現象は, 初期転位密度の差による 可動転位密度の温度依存とひずみ依存性や回復, 試験中 

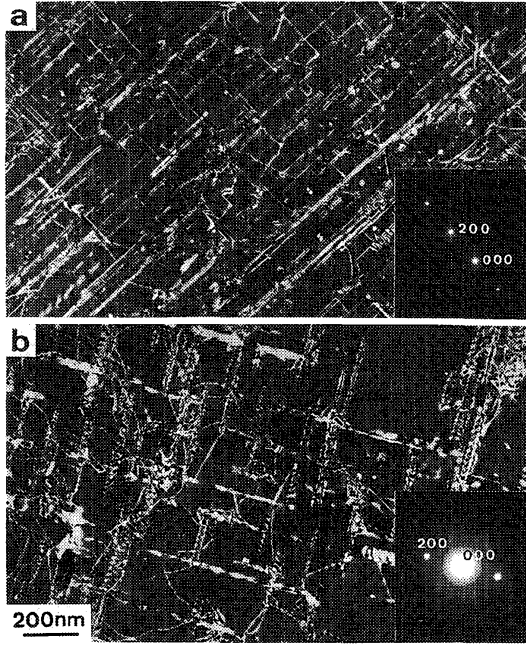

Fig. 12 (200) dark field images of creep tested specimens at $573 \mathrm{~K}$ for $187 \mathrm{ks}$ after T6 treatment. (a) composite $\mathrm{A}$ deformed $2.8 \%$ under a stress of $60 \mathrm{MPa}$, (b) $6061 \mathrm{C}$ alloy deformed 2\% under a stress of $43.6 \mathrm{MPa}$.

の時効の進行, 可動転位と添加粒子との相互作用などに よるものと考えられる。

Fig. 12に, T6 処理後の複合材料 A と6061C 合金を, 同じ $573 \mathrm{~K} て ゙ 187 \mathrm{ks}$ クープ試験した後, 透過電子顕微 鏡で観察した (200) 暗視野像を示す。複合材料(a)，6061 合金 (b) ともに, Fig. 6 に示したT6処理後の析出組織 とは大きく異なり, 析出物が粗大化し, クリープ試験中 に時効が進行していることがわかる。しかし, その析出 物のサイズは複合材料の方が微細であり, クリープ試験 中の時効の進行が遅いように見える。

\section{4. 結言}

（1）溶体化処理後水水焼入れ状態の降伏応力は, 複合 材料（Comral-85）の方が6061合金より40〜85 MPa 程 度高い。これは主に，焼入れ中に強化粒子とマトリック スの熱膨張係数の差により生じた転位の存在に起因して いるものと考光られる。

（2） $448 \mathrm{~K}$ に打ける時効硬化曲線の最高強度に達する 時効時間は, 複合材料と6061合金の間に系統的な差は見 られない。また，時効により強度差は小さくなる。

(3) 室温での圧縮試験による応力ーひずみ曲線から求 めた加工硬化率は, 複合材料の方が大きい。このこと は, 粒子の分散が加工による転位密度の増加を促進する ことを意味している。

（4） T6 処理した複合材料の降伏応力および加工硬化 率の試験温度上昇による低下の割合は, ともに複合材料
の方が6061合金より大きい。

（5） T6 処理した複合材料では， $473 \mathrm{~K}$ か $673 \mathrm{~K}$ ま でのクリープ試験温度の上昇に伴い，応力指数 $n$ 値は 8.3から4.8まで低下する。また，これらの温度範囲にお ける複合材料の $n$ 值は, 6061合金より大きい。

おわりに，複合材料と組織写真（Fig. 1) を提供され た Comalco Research Centerの K. Xia 博士，および化 学分析に協力された住友軽金属工業(㑣技術研究所に感謝 致します。また，実験に協力された九州大学大学院渡辺 万三志氏に感謝します。本研究の一部は軽金属奖学会の グループ研究助成金によって行われたものであり，付記 して感謝の意を表します。

\section{参 考 文 献}

1）落合庄治郎，長村光造：アルミニウムの組織と性 質, 軽金属学会, (1991), 397 .

2) I. J. Toth, W. D. Brentnall and B. D. Menke: J. Metals, 24 (1972), 19.

3）落合庄治郎, 長村光造 : 軽金属, 38 (1988), 685 .

4）小原嗣郎：軽金属, 40 (1990), 703.

5) M. J. Couper and K. Xia: Metal Matrix Composites-Processing, Microstructure and Properties, (ed. N. Hansen, D. Juul Jensen, T. Leffers, H. Lilholt, T. Lorentzen, A. S. Pedersen, O. B. Pedersen and B. Ralph), Risø National Laboratory, (1991), 291.

6) M. J. Couper, B. R. Crawford, J. R. Griffiths and K. Xia: Proc. of the Joint FEFG/ICF Intl. Conf. on Fracture of Engineering Materials and Structures, (ed. S. H. Teoh and K. H. Lee), Elsevier, London, (1991), 188.

7) G. A. Edwards, J. Y. Yao, M. J. Couper and G. L. Dunlop: Aluminium Alloys, Their Physical and Mechanical Properties (ICAA3), (ed. L. Amberg, O. Lohne, E. Nes and N. Ryum), Norwegian Institute of Technology, 1 (1992), 525.

8) Y. Ma, K. Xia, J. L. Mihelich and T. G. Langdon: Advanced Composites'93, TMS, (in press).

9) J. Y. Yao, G. A. Edwards, M. J. Couper and G. L. Dunlop: Aluminium Alloys, Their Physical and Mechanical Properties (ICAA3), (ed. L. Amberg, O. Lohne, E. Nes and N. Ryum), Norwegian Institute of Technology, 1 (1992), 429.

10) I. Dutta, S. M. Allen and J. L. Hafley: Metall. Trans. A, 22A (1991), 2553.

11) L. F. Mondolfo: Aluminium Alloys, Structure and Properties, Butterworths, (1976), 566.

12) T. G. Nieh: Metall. Trans. A, 15A (1984), 139.

13) J. E. Bird, A. K. Mukherjee and J. E. Dorn: Quantitative Relation Between Properties and Microstructure, (ed. D. G. Brandon and A. Rosen), Israel Universities Press, (1969), 255. 